\title{
Allelopathic efficacy of aqueous extracts of Zingiber officinale Rosc. on germination, vigour, growth and yield of Vigna radiata L.
}

\author{
P. Basalingamma, N. K. Hemanth Kumar*, Shobha Jagannath \\ Department of Studies in Botany, University of Mysore, Manasagangotri, Mysore-570 006, India.
}

\begin{tabular}{|c|c|}
\hline ARTICLE INFO & ABSTRACT \\
\hline Article history: & \multirow{6}{*}{$\begin{array}{l}\text { In the present study efficacy of aqueous extracts of rhizome, stem and leaves of Zingiber officinale were studied } \\
\text { on germination, growth and yield parameters of Vigna radiata. Seed germination and its associated parameters } \\
\text { like vigour index, tolerance index, root and shoot length, fresh and dry weight were found to be decreased } \\
\text { considerably as the concentration of stem and leaves extracts increased, when compared to control. Where as in } \\
\text { rhizome extract the maximum values were observed in } 10 \% \text { concentration for all parameters when compared to } \\
\text { control. On the converse the phytotoxicity was found to be increased in stem and leaves extracts as the } \\
\text { concentration increased when compared to control. All the measured yield parameters like height of the plant, } \\
\text { number of leaves per plant, number of branches per pant, number of pods per plant and number of seeds per pod } \\
\text { were found to be decreased as the concentration of leaves and stem extracts increased when compared to control. } \\
\text { On the other hand in rhizome extract the maximum values were observed in } 10 \% \text { concentration when compare to } \\
\text { control and all other concentrations. In all the above parameters were studied the maximum and minimum values } \\
\text { were recorded in control and 50\% concentrations in stem and leaves extracts whereas in rhizome extract } \\
\text { maximum and minimum values were recorded in } 10 \% \text { and } 50 \% \text { concentrations respectively. }\end{array}$} \\
\hline Received on: 17/09/2015 & \\
\hline Revised on: 06/10/2015 & \\
\hline Accepted on: 18/10/2015 & \\
\hline Available online: $22 / 10 / 2015$ & \\
\hline $\begin{array}{l}\text { Key words: } \\
\text { Allelopathy, germination, } \\
\text { phytotoxicity. }\end{array}$ & \\
\hline
\end{tabular}

\section{INTRODUCTION}

The research and development in the field of allelopathy is most important and necessity for the improvement of agriculture, forestry and global environment [1]. In nature plants grow together by inhibiting or stimulating the growth of other plants, such plants showed a inhibition zone around them. Ecosystems infested with such dominating weeds showed drastic changes in their structure and function.

[2] Defined allelopathy as the process where plant releases toxic compounds into the environment, resulting in detrimental effect on other nearby growing plants in the same habitat. Another phase in allelopathy is autointoxication it is a process in which chemicals produced from the plants degraded in soil and inhibits its own growth, as result there will be reduction in the plant productivity in natural vegetation.

The role of allelochemicals is directly or indirectly used for weed management using the inhibitory potential of different allelopathic crops and trees for weed management [3,4]. Allelochemicals may be involved in plant- plant, plant-insect chemical communication [5]. Use of allelopathic herbicides or

* Corresponding Author

N. K. Hemanth Kumar, Department of Studies in Botany,

University of Mysore, Manasagangotri, Mysore-570 006, India.

Email:nkhemanthkumar@yahoo.in pesticides is a programmatic substitute for synthetic herbicides because allelopathic herbicides do not have residual or toxic effects [6]. Inhibitory effect of allelopathic compounds is attributed by the blockage of physiological and biochemical metabolisms in the plant and at low concentrations allelochemicals promote the growth and impart resistance against biotic and abiotic stresses [7].

Application of allelopathic water extracts to the plants at low concentrations increase germination and growth of crop and can be a cost-effective and efficient way to promote growth and to enhance crop productivity [8,9]. Usage of high concentrations allelopathic water extracts decreased the weed density and biomass. In addition to water extracts allelopathy can play effective role in controlling weeds by incorporating allelopathic residues in soil, mulching of residues also suppress the weed flora [10,11]. Insect pest control through the allelochemicals is a natural phenomenon, it is beneficial tool to control harmful insects organically, resistance of insects pests towards the synthetic chemicals can be reduced by the use of allelopathic pesticides.

\section{MATERIALS AND METHODS}

\section{Collection of seed sample and plant materials}

The plant materials like ginger leaves, stem and rhizome were collected from chamarajanagar district Karnataka India. The certified seed sample cultivar KKM3 was collected from GKVK Bangalore. 


\section{Extraction of plant materials}

The collected plant materials like leaves, stem and rhizomes were shade dried for 30 days and made in to fine powder with mixer. 100 gram of each rhizome, leaf and stem powdered sample was suspended in $100 \mathrm{ml}$ distilled water and kept in rotary shaker for 2 days. Extracts were filtered in muslin cloth. The obtained extract was stored in refrigerator to reduce the degradation of allelochemicals for further studies.

\section{Germination and morphological studies}

Healthy and uniform seeds were selected; seeds were sown in triplicates in polycups filled with soil, sand and vermicompost in a proportion of 6:2:2 respectively. To each of polycups, aqueous extracts of $5 \mathrm{ml}$ of concentrations like $10 \%, 20$ $\%, 30 \%, 40 \%$ and $50 \%$ was added and distilled water is taken as control. Germination percentage, root length and shoot length were determined following the method of [12], vigour index, tolerance index, percentage of phytotoxicity and fresh weight and dry weight following the method of [13-16].

\section{Determination of yield in green house condition:}

Healthy and uniform seeds of green gram were selected for sowing. Each pot was sown with five seeds and the seeds were placed equidistantly in order to provide sufficient space and light for the proper growth and development of the plants. The pots were also provided with $20-30 \mathrm{ml}$ of respective concentrations of the stem, rhizome and leaf aqueous extracts of ginger until the germination of seeds. Once the seeds germinated the pots were supplied only with tap water. After the complete growth and development of the plants, the matured pods were harvested. The difference in number of pods and weight of pods amongst various concentrations and the control were analyzed and recorded.

\section{RESULTS AND DISCUSSION}

In the present study germination percentage was found to be decreased with the increased in concentration of ginger leaf and stem extracts. However rhizome extract stimulated the growth at $10 \%$ concentration and gradually decreased with the increase in concentration when compared to control. The maximum and minimum \% of germination was recorded in control and $50 \%$ leaf and stem extract concentration; however in rhizome extract it was found to be $10 \%$ and $50 \%$ respectively, when compared to control. In leaf and stem extract the percentage of germination decreased from 93.3 to $59.9 \%$ and 86.6 to $63.2 \%$ from 10 to $50 \%$ concentrations respectively when compared to control. [17] Concluded that Vitex negundo had inhibitory effect on germination percentage of green gram at higher concentration and exhibited stimulatory effect at lower concentration. Inhibition increased with the increase in concentration. They stated that the reason for inhibitory and stimulatory effects was due to the presence of allelochemicals in leaf extract of $V$. negundo. Vigour index of green gram seedlings decreased with the increase in concentration of ginger leaf and stem extracts, where as in rhizome extract at 10 $\%$ concentration showed stimulatory effect there after decreased with increase in concentration. The vigor index decreased from 5 to $37 \%$ and 25 to $66 \%$ in stem and leaf extract respectively when compared to control. This results correlates with [18] where the extracts of Tectona grandis produced allelopathic effect on seedling vigour of gram seeds, the reduction in vigour index of gram seedlings may be due to the due to reduced germination and shoot length. [19] studied the allelopathic effect of Parthenium hysterophorus different plant part extracts on vigour index of green gram and soybean, they observed that out of all the plant parts leaf extracts were most inhibitory as the concentration increased, other extracts showed stimulatory effect this stimulatory effect is may be due to the presence of auxin like substances in the extract of parthenium. The shoot and root length of green gram seedlings gradually decreased with the increase in concentration of ginger leaf and stem extracts, where as rhizome extract at $10 \%$ concentration showed stimulatory effect and there after decreased with increase in concentration (Table:2). In stem and leaf extract the shoot and root length was found to be decreased from 32 to $58 \%, 5$ to $44 \%$ and 20 to $67 \%, 13$ to $62 \%$ from 10 to $50 \%$ concentrations respectively when compared to control. On the other hand in rhizome extract the root and shoot length increased $3.2 \%$ and $5 \%$ respectively in $10 \%$ concentration. This results were correlated with [18] where the extracts of Tectona grandis showed allelopathic effect on shoot and root length of gram seeds, the reduction in shoot and root length of gram seedlings may be due to the due to reduced germination. [20] Studied the allelopathic effect of Lawsonia inermis on shoot and root length of green gram, the results showed a decreasing trend with increasing extract concentrations. The allelopathic effect of Vitex negundo on seedling growth of green gram, the results showed a stimulatory effect at lower concentration and inhibitory effect at higher concentrations, the stimulatory effect may be due to the presence of different levels of allelochemicals in the leaf extracts of $V$. negundo [17]. The present study showed a gradual decrease in fresh and dry weight of green gram seedlings treated with different concentrations of ginger stem and leaf extracts. Fresh and dry weight was found to be decreased from 21 to $31 \%, 3$ to $27 \%$ and 10 to $50 \%, 25$ to $50 \%$ from 10 to $50 \%$ concentrations respectively when compared to control. On the other hand in rhizome extract at $10 \%$ concentration the fresh and dry weight increased $0.6 \%$ and $8.3 \%$ respectively. This result was correlated with [18] the green gram seedlings treated with leaf extract of Tectona grandis showed a significant decrease in fresh and dry weight of green gram seedlings as the concentration increased when compared to control. The reduction in fresh and dry weight of green gram seedlings treated with Lawsonia inermis and Tridax procumbens plant extracts, this inhibitory effect is may be due to the presence of allelochemicals in the plant extract [20]. In the present study the vegetative growth parameters such as total number of leaves per plant, height of the plant, number of branches per plant, number of pods per plant and number of seeds per pod were found 
to be decreased with increased in concentration of ginger stem and leaf extract and there was increase at $10 \%$ rhizome extract when compared to control (Table 3). In stem and leaf extracts height of the plants were decreased from 9.4 to $53.4 \%$ and 5.0 to $38 \%$ from 10 to $50 \%$ concentrations respectively when compared to control. In rhizome extract height of the plant was increased $5.6 \%$ when compared to all other concentrations including control. The number of leaves per plant and number of branches per plant were found to be decreased as stem and leaf concentration increased when compared to control. In stem and leaf extract number of leaves per plant and number of branches per plant decreased from 8.2 to $38.5 \%, 13.4$ to $53.4 \%$ and 5 to $28.5 \%, 0.4$ to $34.9 \%$ from 10 to $50 \%$ concentrations respectively. However in rhizome extract number of leaves per plant and number of branches per plant increased 15 and $19 \%$ respectively when compared to control. In stem and leaf extracts number of pods per plant and number of seeds per pod were decreased from 6 to $47 \%$, 6.1 to 37.5 and 5.42 to $34.2,7.5$ to 38.4 from 10 to $50 \%$ concentrations respectively when compared to control. On the other hand in rhizome extract at $10 \%$ concentration number of pods per plant and number of seeds per pod were found to be increased 15 and $19 \%$ respectively when compared to control. [21] investigated the effect of different concentrations of leaf litter of Lantana camara on vegetative growth parameters of green gram, results showed inhibitory effect with the increase in concentration. This inhibitory effect on plant height may be due to inhibition of biosynthesis of gibberellins, which are responsible for cell elongation and plant height.

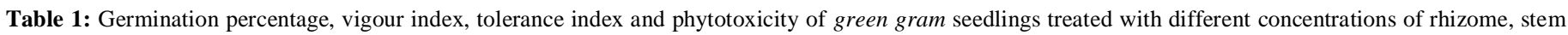
and leaf extract of ginger.

\begin{tabular}{|c|c|c|c|c|}
\hline Parameters & Germination percentage & Vigour index & Tolerance index & Phytotoxicity \\
\hline \multicolumn{5}{|c|}{ Different concentrations of rhizome extract } \\
\hline Control & $89.96 \pm 3.45^{\mathrm{a}}$ & $1177.29 \pm 182.8^{\mathrm{b}}$ & $100.00 \pm 0.00 \mathrm{a}$ & $0.00 \pm 0.00^{\mathrm{e}}$ \\
\hline $10 \%$ & $93.30 \pm 3.25^{\mathrm{a}}$ & $1397.58 \pm 207.15^{\mathrm{a}}$ & $58.86 \pm 2.00^{\mathrm{b}}$ & $-9.543 \pm 0.187^{\mathrm{f}}$ \\
\hline $20 \%$ & $79.90 \pm 3.65^{\mathrm{b}}$ & $940.11 \pm 72.81^{\mathrm{c}}$ & $49.05 \pm 2.00^{\mathrm{c}}$ & $12.66 \pm 0.228^{\mathrm{d}}$ \\
\hline $30 \%$ & $72.46 \pm 2.15^{\mathrm{c}}$ & $742.03 \pm 60.8^{\mathrm{d}}$ & $34.55 \pm 2.00^{\mathrm{d}}$ & $21.543 \pm 0.31^{\mathrm{c}}$ \\
\hline $40 \%$ & $66.63 \pm 3.30^{\mathrm{d}}$ & $641.03 \pm 49.9^{\mathrm{e}}$ & $26.50 \pm 2.0^{\mathrm{e}}$ & $22.70 \pm 0.180^{\mathrm{b}}$ \\
\hline $50 \%$ & $59.96 \pm 3.45^{\mathrm{e}}$ & $544.72 \pm 74.14^{\mathrm{f}}$ & $24.56 \pm 2.02^{\mathrm{e}}$ & $47.34 \pm 0.183^{\mathrm{a}}$ \\
\hline \multicolumn{5}{|c|}{ Different concentrations of stem extract } \\
\hline Control & $89.96 \pm 3.45^{\mathrm{a}}$ & $1647.19 \pm 168.9^{\mathrm{a}}$ & $100 \pm 00.0^{\mathrm{a}}$ & $0.00 \pm 0.00^{\mathrm{f}}$ \\
\hline $10 \%$ & $86.63 \pm 3.30^{\mathrm{b}}$ & $1579.75 \pm 185.4^{\mathrm{b}}$ & $90.59 \pm 2.37^{\mathrm{b}}$ & $6.52 \pm 0.32^{\mathrm{e}}$ \\
\hline $20 \%$ & $77.00 \pm 3.60^{\mathrm{c}}$ & $1472.02 \pm 185.0^{\mathrm{c}}$ & $77.88 \pm 1.99^{\mathrm{c}}$ & $10.37 \pm 0.17^{\mathrm{d}}$ \\
\hline $30 \%$ & $73.66 \pm 3.51^{\mathrm{d}}$ & $1296.43 \pm 55.6^{\mathrm{d}}$ & $63.73 \pm 2.07^{\mathrm{d}}$ & $11.66 \pm 0.25^{\mathrm{c}}$ \\
\hline $40 \%$ & $66.63 \pm 3.30^{\mathrm{e}}$ & $1177.29 \pm 182.8^{\mathrm{d}}$ & $49.05 \pm 2.00^{\mathrm{e}}$ & $14.56 \pm 0.22^{\mathrm{b}}$ \\
\hline $50 \%$ & $63.27 \pm 3.25^{\mathrm{f}}$ & $1030.88 \pm 40.7^{\mathrm{e}}$ & $27.54 \pm 2.08^{f}$ & $18.50 \pm 0.31^{\mathrm{a}}$ \\
\hline \multicolumn{5}{|c|}{ Different concentrations of leaf extract } \\
\hline Control & $89.96 \pm 3.45^{\mathrm{a}}$ & $1635.11 \pm 63.10^{\mathrm{a}}$ & $100 \pm 00.00^{\mathrm{a}}$ & $0.00 \pm 0.00^{\mathrm{d}}$ \\
\hline $10 \%$ & $86.63 \pm 3.30^{\mathrm{b}}$ & $1223.16 \pm 87.57^{b}$ & $77.81 \pm 2.09^{\mathrm{b}}$ & $6.523 \pm 0.24^{f}$ \\
\hline $20 \%$ & $73.00 \pm 2.00^{\mathrm{c}}$ & $1177.29 \pm 182^{\mathrm{c}}$ & $57.80 \pm 1.88^{\mathrm{c}}$ & $7.6 \pm 0.283^{\mathrm{e}}$ \\
\hline $30 \%$ & $63.66 \pm 3.51^{d}$ & $1000.10 \pm 22.60^{\mathrm{d}}$ & $52.00 \pm 2.00^{\mathrm{d}}$ & $15.59 \pm 0.30^{\mathrm{c}}$ \\
\hline $40 \%$ & $60.33 \pm 3.51^{\mathrm{e}}$ & $801.44 \pm 25.79^{\mathrm{e}}$ & $24.68 \pm 2.20^{\mathrm{e}}$ & $39.523 \pm 0.171^{b}$ \\
\hline $50 \%$ & $57.00 \pm 3.00^{\mathrm{f}}$ & $553.51 \pm 109.40^{\mathrm{f}}$ & $14.89 \pm 2.12^{f}$ & $49.55 \pm 0.21^{\mathrm{a}}$ \\
\hline
\end{tabular}

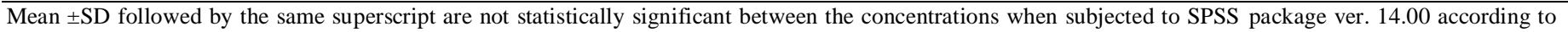
Tukey's mean range test at 5\% level.

Table 2: Fresh and Dry weight, shoot and root length of green gram seedlings treated with different concentrations of rhizome, stem and leaf extract.

\begin{tabular}{|c|c|c|c|c|}
\hline Parameters & Fresh weight (g/plant) & Dry weight (g/plant) & Shoot length & Root length \\
\hline \multicolumn{5}{|c|}{ Different concentrations of rhizome extract } \\
\hline Control & $0.326 \pm 0.08^{b}$ & $0.024 \pm 0.011^{\mathrm{a}}$ & $7.84 \pm 1.64^{b}$ & $8.63 \pm 0.26^{b}$ \\
\hline $10 \%$ & $0.328 \pm 0.032^{\mathrm{a}}$ & $0.026 \pm 0.010^{\mathrm{a}}$ & $8.63 \pm 0.269^{\mathrm{a}}$ & $10.676 \pm 0.31^{\mathrm{a}}$ \\
\hline $20 \%$ & $0.316 \pm 0.023^{\mathrm{b}}$ & $0.022 \pm 0.010^{\mathrm{a}}$ & $7.43 \pm 0.315^{\mathrm{c}}$ & $7.618 \pm 0.14^{\mathrm{c}}$ \\
\hline $30 \%$ & $0.266 \pm 0.090^{\mathrm{c}}$ & $0.023 \pm 0.005^{\mathrm{a}}$ & $6.476 \pm 1.66^{\mathrm{d}}$ & $7.24 \pm 0.098^{\mathrm{d}}$ \\
\hline $40 \%$ & $0.260 \pm 0.040^{\mathrm{c}}$ & $0.020 \pm 0.010^{\mathrm{b}}$ & $6.022 \pm 2.745^{\mathrm{e}}$ & $6.566 \pm 0.28^{\mathrm{e}}$ \\
\hline $50 \%$ & $0.226 \pm 0.092^{c}$ & $0.016 \pm 0.01^{\mathrm{c}}$ & $5.816 \pm 1.77^{\mathrm{f}}$ & $5.773 \pm 0.13^{\mathrm{f}}$ \\
\hline \multicolumn{5}{|c|}{ Different concentrations of stem extract } \\
\hline Control & $0.413 \pm 0.111^{\mathrm{a}}$ & $0.040 \pm 0.0100^{\mathrm{a}}$ & $5.515 \pm 1.833^{\mathrm{a}}$ & $7.823 \pm 0.126^{\mathrm{a}}$ \\
\hline $10 \%$ & $0.326 \pm 0.055^{\mathrm{b}}$ & $0.036 \pm 0.005^{\mathrm{a}}$ & $5.332 \pm 1.671^{\mathrm{a}}$ & $7.436 \pm 0.082^{\mathrm{a}}$ \\
\hline $20 \%$ & $0.313 \pm 0.060^{\mathrm{b}}$ & $0.030 \pm 0.000^{\mathrm{b}}$ & $4.536 \pm 0.143^{b}$ & $7.1 \pm 0.163^{\mathrm{a}}$ \\
\hline $30 \%$ & $0.306 \pm 0.090^{\mathrm{c}}$ & $0.023 \pm 0.005^{\mathrm{c}}$ & $3.44 \pm 0.180^{\mathrm{c}}$ & $6.753 \pm 0.159^{b}$ \\
\hline $40 \%$ & $0.293 \pm 0.015^{\mathrm{c}}$ & $0.020 \pm 0.010^{\mathrm{c}}$ & $3.1 \pm 0.163^{\mathrm{c}}$ & $5.623 \pm 0.197^{\mathrm{c}}$ \\
\hline $50 \%$ & $0.286 \pm 0.075^{c}$ & $0.020 \pm 0.010^{\mathrm{c}}$ & $2.353 \pm 0.142^{\mathrm{d}}$ & $4.343 \pm 0.211^{\mathrm{d}}$ \\
\hline \multicolumn{5}{|c|}{ Different concentrations of leaf extract } \\
\hline Control & $0.33 \pm 0.01^{\mathrm{a}}$ & $0.04 \pm 0.01^{\mathrm{a}}$ & $7.7 \pm 0.163^{\mathrm{a}}$ & $14.596 \pm 0.263^{\mathrm{a}}$ \\
\hline $10 \%$ & $0.326 \pm 0.05^{\mathrm{b}}$ & $0.03 \pm 0.05^{\mathrm{a}}$ & $6.113 \pm 0.147^{b}$ & $12.626 \pm 0.135^{\mathrm{b}}$ \\
\hline $20 \%$ & $0.32 \pm 0.04^{\mathrm{b}}$ & $0.03 \pm 0.00^{\mathrm{a}}$ & $5.6 \pm 0.163^{\mathrm{c}}$ & $10.676 \pm 0.318^{\mathrm{c}}$ \\
\hline $30 \%$ & $0.29 \pm 0.02^{\mathrm{c}}$ & $0.023 \pm 0.00^{\mathrm{b}}$ & $4.7 \pm 0.163^{\mathrm{d}}$ & $8.63 \pm 0.269^{\mathrm{d}}$ \\
\hline $40 \%$ & $0.25 \pm 0.03^{\mathrm{c}}$ & $0.02 \pm 0.01^{\mathrm{b}}$ & $3.6 \pm 0.163^{\mathrm{e}}$ & $7.653 \pm 0.236^{\mathrm{e}}$ \\
\hline $50 \%$ & $0.24 \pm 0.05^{\mathrm{c}}$ & $0.02 \pm 0.01^{\mathrm{b}}$ & $2.566 \pm 0.155^{\mathrm{f}}$ & $5.573 \pm 0.277^{\mathrm{f}}$ \\
\hline
\end{tabular}

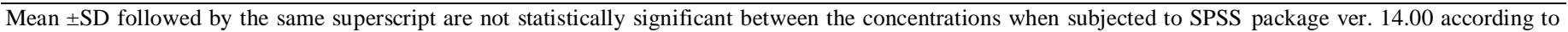
Tukey's mean range test at 5\% level. 
Table 3: vegetative growth and yield parameters of green gram seedlings treated with different concentrations of ginger stem, leaf and rhizome extracts.

\begin{tabular}{|c|c|c|c|c|c|}
\hline Concentration & Height of the plant & Number of leaves/plant & Number of branches/plant & Number of pods/plant & Number of seeds/pod \\
\hline \multicolumn{6}{|c|}{ Different concentrations of ginger rhizome extract } \\
\hline Control & $47 \pm 0.40^{\mathrm{b}}$ & $4.33 \pm 0.47^{\mathrm{b}}$ & $6.66 \pm 0.47^{\mathrm{b}}$ & $5.33 \pm 0.47^{\mathrm{a}}$ & $11.53 \pm 0.41^{\mathrm{b}}$ \\
\hline $10 \%$ & $49.66 \pm 1.31^{\mathrm{a}}$ & $5 \pm 0.81^{\mathrm{a}}$ & $7.87 \pm 0.226^{\mathrm{a}}$ & $5.66 \pm 0.475^{\mathrm{a}}$ & $12.44 \pm 0.56^{\mathrm{a}}$ \\
\hline $20 \%$ & $46.53 \pm 1.04^{\mathrm{c}}$ & $3.33 \pm 0.47^{\mathrm{c}}$ & $6.33 \pm 0.47^{\mathrm{b}}$ & $4.66 \pm 0.47^{\mathrm{b}}$ & $10.97 \pm 0.74^{\mathrm{b}}$ \\
\hline $30 \%$ & $43.63 \pm 1.65^{\mathrm{d}}$ & $3 \pm 0.00^{\mathrm{c}}$ & $5.66 \pm 0.47^{\mathrm{c}}$ & $4.33 \pm 0.47^{\mathrm{b}}$ & $9.70 \pm 0.13^{\mathrm{c}}$ \\
\hline $40 \%$ & $41.66 \pm 0.47^{\mathrm{e}}$ & $2.66 \pm 0.47^{\mathrm{d}}$ & $5 \pm 0.0^{\mathrm{d}}$ & $3.33 \pm 0.47^{\mathrm{c}}$ & $7.87 \pm 0.22^{\mathrm{d}}$ \\
\hline $50 \%$ & $39.5 \pm 1.634^{\mathrm{f}}$ & $2.33 \pm 0.47^{\mathrm{d}}$ & $4.66 \pm 0.47^{\mathrm{d}}$ & $3.00 \pm 0.0^{\mathrm{c}}$ & $5.62 \pm 0.12^{\mathrm{e}}$ \\
\hline \multicolumn{6}{|c|}{ Different concentrations of ginger stem extract } \\
\hline Control & $43.63 \pm 1.65 a$ & $4.33 \pm 0.47^{\mathrm{a}}$ & $7 \pm 0.81^{\mathrm{a}}$ & $5.66 \pm 0.47^{\mathrm{a}}$ & $12.16 \pm 1.64^{\mathrm{a}}$ \\
\hline $10 \%$ & $39.5 \pm 1.63 b$ & $4 \pm 0.81^{\mathrm{a}}$ & $6.66 \pm 0.47^{\mathrm{a}}$ & $5.33 \pm 0.47^{\mathrm{a}}$ & $11.53 \pm 0.41^{\mathrm{b}}$ \\
\hline $20 \%$ & $34.46 \pm 1.06 \mathrm{c}$ & $4 \pm 0.0^{\mathrm{a}}$ & $6.33 \pm 0.47^{\mathrm{b}}$ & $4.66 \pm 0.47^{\mathrm{b}}$ & $10.69 \pm 0.04^{\mathrm{c}}$ \\
\hline $30 \%$ & $31.16 \pm 1.02 \mathrm{c}$ & $3.66 \pm 0.47^{\mathrm{b}}$ & $6.33 \pm 0.47^{\mathrm{b}}$ & $4.33 \pm 0.47^{\mathrm{b}}$ & $10.21 \pm 0.28^{\mathrm{c}}$ \\
\hline $40 \%$ & $28.83 \pm 0.62 \mathrm{~d}$ & $3 \pm 0.00^{\mathrm{b}}$ & $5.66 \pm 0.47^{\mathrm{c}}$ & $3.33 \pm 0.47^{\mathrm{c}}$ & $9.59 \pm 0.30^{\mathrm{d}}$ \\
\hline $50 \%$ & $20.33 \pm 2.05 \mathrm{e}$ & $2.66 \pm 0.47^{\mathrm{c}}$ & $5 \pm 0.0^{\mathrm{c}}$ & $3 \pm 0.0^{\mathrm{c}}$ & $8 \pm 0.81^{\mathrm{e}}$ \\
\hline \multicolumn{6}{|c|}{ Different concentrations of ginger leaf extract } \\
\hline Control & $41.66 \pm 0.47 \mathrm{a}$ & $5 \pm 0.81^{\mathrm{a}}$ & $6.66 \pm 0.47^{\mathrm{a}}$ & $5.33 \pm 0.81^{\mathrm{a}}$ & $12.44 \pm 0.56^{\mathrm{a}}$ \\
\hline $10 \%$ & $39.5 \pm 1.63 \mathrm{a}$ & $4.33 \pm 0.47^{\mathrm{b}}$ & $6.63 \pm 0.47^{\mathrm{a}}$ & $5.00 \pm 0.47^{\mathrm{a}}$ & $11.5 \pm 0.70^{\mathrm{b}}$ \\
\hline $20 \%$ & $38 \pm 0.81 \mathrm{a}$ & $3.33 \pm 0.47^{\mathrm{c}}$ & $6.00 \pm 0.47^{\mathrm{a}}$ & $5.00 \pm 0.81^{\mathrm{a}}$ & $10.93 \pm 1.08^{\mathrm{c}}$ \\
\hline $30 \%$ & $34.5 \pm 0.40 \mathrm{a}$ & $3 \pm 0.0^{\mathrm{c}}$ & $6.00 \pm 0.0^{\mathrm{a}}$ & $4.66 \pm 0.47^{\mathrm{b}}$ & $9.8 \pm 1.55 \mathrm{~d}$ \\
\hline $40 \%$ & $31.16 \pm 0.84 b$ & $2.66 \pm 0.47^{\mathrm{d}}$ & $5.33 \pm 0.94^{\mathrm{b}}$ & $4.33 \pm 0.47^{\mathrm{b}}$ & $8.8 \pm 1.65^{\mathrm{e}}$ \\
\hline $50 \%$ & $25.83 \pm 0.62 b$ & $2.33 \pm 0.47^{\mathrm{d}}$ & $4.33 \pm 0.47^{\mathrm{c}}$ & $3.33 \pm 0.47^{\mathrm{c}}$ & $7.66 \pm 2.49^{f}$ \\
\hline
\end{tabular}

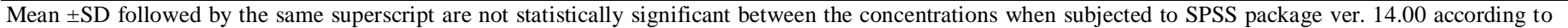

Tukey's mean range test at $5 \%$ level.

The reduction in the yield per plant may be due to reduction in production of number of heads per plant and low rate of seed settings which were controlled by reduction in vegetative growth parameters.

\section{REFERENCES}

1. Reigosa MJ, Pedrol M, Gonzales L, Narwal SS. Allelopathy in Ecological Sustainable Agriculture In: Allelopathy:A physiological process with Ecological Implications. Springer, Netherlands, 2006; 537-564.

2. Muller CH. 1969. Allelopathy as a Ridenour, WM and RM Callaway. 2001.

3. Cheema ZA, Khaliq A, Saeed S. Weed control in maize (Zea mays L.) through sorghum allelopathy. Journal of Sustainable Agriculture. 2004; 23: 73-86.

4. Farooq M, Jabran K, Cheema ZA, Wahid A, Siddique KHM. The role of allelopathy in agricultural pest management. Pest Management Science. 2011a; 67; 493-506.

5. Wier TL, Park SW, Vivanco JM. Biological and physiological mechanism mediated by allelochemicals. Current Opinion in Plant Biology, 2004; 7: 472-479.

6. Bhadoria PBS. Allelopathy: a natural way towards weed management. American Journal of Experimental Agriculture. 2011; 1: 7-20.

7. Farooq M, Basra SMA, Wahid A, Ahmad N, Saleem BA. Improving the drought tolerance in rice (Oryza sativa L.) by exogenous application of salicylic acid. Journal of Agronomy and Crop Science. 2009; 195: 237-246.

8. Cheema ZA, Farooq M, Khaliq A. Application of allelopathy in crop production: success story from Pakistan. In: Allelopathy: Current Trends and Future Applications 2012; 113-143.

9. Oudhia P, Kolhe SSS, Tirpathi RS. Allelopathic effect of Blumea lacera L. on rice and common Kharif weeds. Oryza, 1998; 35: 175177.

10. Cheema ZA, Khaliq A, Mubeen M. Response of wheat and winter weeds to foliar application of different plant water extracts of sorghum (Sorghum bicolor). Pakistan Journal of Weed Science Research. 2003; 9: 89-97.

11. Khaliq A, Matloob A, Irshad MS, Tanveer A, Zamir MSI. Organic weed management in maize through integration of allelopathic crop residues. Pakistan Journal of Weed Science Research. 2010; 16: 409-420.
12. ISTA. International rules for seed testing. Seed Science and Technology. 1985; 13: 361-513.

13. Abdul Baki AA, Anderson JD. Vigour determination of soybean seed by multiple criteria. Crop Science. 1973; 3: 630 - 633.

14. Turner LG, Marshal C. Accumulation of zinc by sub cellular fraction of root of Agrostis tennis sibth in relation to zinc tolerance. New Phytology. 1972; 71: 671-676.

15. Chion $\mathrm{CH}$, Muller $\mathrm{CH}$. Allelopathic mechanism of Archtostaphylous glandulosa variety Zazaeisis, Am. Mid Nat. 1972; 88: 324-347.

16. Agarwal RL. Seed technology. Oxford and IBH publishing Co. 1994. New Delhi.

17. Kavitha D, Prabhakaran J, Arumugam K. Allelopathic influence of Vitex negundo L. on germination and growth of greengram (Vigna radiata L. R. Wilczek) and blackgram (Vigna mungo L. Hepper). International Journal of Ayurvedic and Herbal Medicine. 2012; 2(1): 163-170.

18. Das CR, Mondal NK, Aditya P, Datta JK, Banerjee Das K. Allelopathic potentialities of Leachates of Leaf Litter of some selected tree crops on Gram seeds under Laboratory conditions. AJEBS. 2012; 59-65.

19. Suganthi, Pushpa A. Allelopathic effect of Parthenium hysterophores plant and its component on the growth attributes of green gram and soyabean. Helix. 2014; 6: 635-640.

20. Kaveriamma S, Geethambigai S, Subramani A. Phytotoxicity effects of Lawsonia inermis L. on the seed germination and growth performance of selected pulses. International Journal of Research in Botany. 2013; 3(1): 23-26.

21. Gantayet PK, Adhikary SP, Lenka KC, Padhy B. Allelopathic impact of Lantana camara on vegetative growth and yield components of green gram (Phaseolus radiatus). International Journal of Current Microbiology and Applied Sciences. 2014; 3(7): 327-335.

\section{How to cite this article:}

Basalingamma P., Hemanth Kumar N.K. and Shobha Jagannath. Allelopathic efficacy of aqueous extracts of Zingiber officinale Rosc. on germination, vigour, growth and yield of Vigna radiata L. J App Biol Biotech. 2015; 3 (05): 048-051. DOI: 10.7324/JABB.2015.3510 